\title{
RISKS IN THE INVESTMENT ACTIVITY OF POLISH REGIONS
}

\author{
Beata Zofia Filipiak \\ University of Szczecin, Szczecin, Poland \\ e-mail: bfilipiak@wneiz.pl
}

ORCID: 0000-0003-0168-2798

\section{Marek Dylewski}

WSB University, Poznań, Poland e-mail: marek.dylewski@wsb.poznan.pl

ORCID: 0000-0002-5480-5264

(C) 2018 Beata Zofia Filipiak, Marek Dylewski

This is an open access article distributed under the Creative Commons Attribution-NonCommercial-NoDerivs license (http://creativecommons.org/licenses/by-nc-nd/3.0/)

DOI: $10.15611 /$ fins.2018.4.02

JEL Classification: H7, H72, G320

\begin{abstract}
Investment activities executed by regional authorities are exposed to high risk. The risk results from the very essence of investment projects implemented by regions in Poland and can be associated with the failure to meet the regional budget. The purpose of this study is to assess the size of the existing discrepancies between the planned and actually incurred investment expenditure and to find out if there are systematic changes in the level of these discrepancies i subsequent years. This goal was achieved through the presentation of the specific approach to risk measurement in the investment activities of local government units. The research was undertaken by regional self-government units. Empirical research has allowed us to answer three research questions: how great were the disparities between the planned and the actually incurred investment costs in the Polish regions in 2011-2015? Did systematic changes in the level of inconsistency between the planned and the actually incurred costs take place in the observed period? Was the rate of failure to meet investment plans correlated with the rate of failure to meet operational financial plans?
\end{abstract}

Keywords: local government, expenditure, infrastructure, financial risk.

\section{Introduction}

The investments activities executed by regional authorities are exposed to high risk. The risk results from the very essence of the investment projects implemented by the regions in Poland and can be associated with the failure to meet the regional budget. The budget includes the investment plan for a given year, broken down into specific tasks and the funds allocated for their implementation. In order to improve 
the effectiveness of the realised investment projects, it is vital to recognise the risk types associated with this kind of activity. The process of identifying the risk types should be supported with the assessment of the impact of the identified factors on the elementary parameters of the investment project, such as its time, cost, quality and effectiveness.

In this context the problem should be discussed of linking the planned investment expenditure in the regional budgets with their actual implementation. The discrepancies between the plans and the project implementation determine the level of failure to meet the investment objectives incorporated into the regional budgets. This level may be regarded as an indirect measure of the cumulation scale of the impact of individual risk types on the completed and planned investment projects.

The thesis has been adopted that the risk appearing in the voivodship management processes is reflected in the levels of failure to meet the investment objectives in the regional budgets. The purpose of this study is to assess the size of the existing discrepancies between the planned and actually incurred investment expenditure and to find out if there are systematic changes in the level of these discrepancies in subsequent years.

\section{Risk in the investment activity of Polish local government units}

Investment decisions include the decisions about fund allocation to investments both directly addressing social needs and those contributing to satisfying such needs in the future. Economists study investment to better understand fluctuations in the economy's output of goods and services. Investment plays two roles in macroeconomics and in the public sector. First, because it is a large and the most volatile component of spending, sharp changes in investment can have a major impact on aggregate demand and thus growing social needs which are financed from public funds [Ali 2015]. In addition, investment leads to the development of public and social infrastructure [Czempas 2013], which manifests itself in the better quality of public goods and services provided to the public [Stiglitz 2004; Sadowy 2006]. Investments play the role of technical instruments to stimulate sustainable development and affect the economic development of regions, including municipalities [Graczyk 2008; Ali 2015]. Their contemporary feature is to connect public goals with infrastructure and risk [Czempas 2010; Kata 2015]. A review of literature and evaluation reports reveals the common scenario that inadequate risk assessment does not provide enough information for a valid decision, particularly for public sector investment projects in highly uncertain environments, such as a crisis [Bock, Trück 2011].

Investments not only engage regional budgets on a long-term basis but also improve the quality of public services and the standard of tasks being implemented. Moreover, they support development and reduce regional disparities in Europe. They are an important element of building local social and economic capacity as well as 
a measure of economic growth. It is characteristic of such investments that they are exposed to the risk of failure to meet the objectives (including the failure to meet the entry into use deadlines). This means the presence of a risk factor, i.e. a situation that affects the adopted investment objectives that may result in either profit or loss. Risk is measured in terms of the probability of an event to occur as well as of its impact and consequences [Pfeffer 1956; Knight 2005; Filipiak 2011; Kata 2015]. Risk is associated with any activity, it is also connected with uncertainty referring to the negative effects and positive deviations from the outcome of the implemented investment project. This opinion is shared by many authors writing on this subject. Risk changes along with uncertainty because the greater the uncertainty scope, the higher the risk. ${ }^{1}$ It should also be noted that risk increases with the volume of capital involved in the investment project.

Numerous discussions about the notion of risk and its classification allow to refer to such a risk categorisation that reflects the existing groups of risk factors. ${ }^{2} \mathrm{We}$ can distinguish:

- systematic risk, also referred to as overall risk, being the effect of external forces which the regional authorities, as the entity exposed to risk, have no influence on - which means that this particular risk cannot be controlled. The sources of systematic risk are, for instance, the changes in the economic cycle or social/ political/economic situation, legislation, etc.

- specific risk, also referred to as operational risk, is conditioned by microeconomic factors inherent in the regional authorities' decisions as well as by the factors created by the immediate environment. This category of risk embraces: management quality risk, risk of becoming dependent on a single contract, customer solvency risk and credit risk. ${ }^{3}$

Vose [2000] categorised risk classifications into the following exemplifying sections: Administration, Project Acceptance, Commercial, Communication, Environmental, Political, Resources, Strategic, Subcontractor, Technical, Financial, Knowledge and Information, and Legal. Numerous classifications of risk types have been undertaken. A review of literature and research reveals a common scenario for risk classification [Vose 2000; Nahotko 2001; Jaafari 2001; Piyatrapoomi, Kumar, Setunge 2004; Poniatowicz et al. 2010; Filipiak 2010, 2011; Bock, Trück 2011; Czempas 2013]:

- strategic - relating to the long-term goals of the unit ${ }^{4}$,

\footnotetext{
${ }^{1}$ See in particular: [Kulp 1928; Pfeffer 1956; Knight 2005; Grzybowski 1984; Poniatowicz et al. 2010; Filipiak 2011; Pera 2012; Czempas 2013].

${ }^{2}$ See more on risk classification: [Roy, Singell, 1987, Rowe 1997; Jaafari 2001; Piyatrapoomi, Kumar, Setunge 2004; Knight 2005; Tarczyński, Mojsiewicz 2001; Jajuga, Jajuga 1996; Czempas 2010; Filipiak 2011; Kamiński 2012; Poniatowicz 2014; Kata 2015].

3 Proposed by: [Kulp 1928; Rowe 1997; Poniatowicz et al. 2010; Filipiak 2010; Kamiński 2012; Pera 2012].

${ }^{4}$ As defined in Komunikat nr 6 Ministra Finansów z 6 grudnia 2012.
} 
- tactical - focusing on the manner of the operationalization of the activities that are necessary to achieve the adopted objectives and tasks ${ }^{5}$,

- operational.

Investment activity in the Polish regions [Nahotko 2001] is exposed to operational risk (i.e. inherent in the day-to-day operation of regional authorities, thus being associated with the implementation of the current tasks included in the budget and with the sufficiency of funds allocated to the investment budget), financial liquidity risk (concerning the ability to maintain liability), exchange rate risk (encompassing the part of financial management that deals with operations in foreign currencies), interest rate risk (resulting from economic transactions where prices are expressed as a percentage of value), credit risk (associated with the region's own or its customer's credit worthiness) and finally, financial risk (inherent in the investment project financing structure) ${ }^{6}$ We should not forget the impact of the risk inherent in social or economic changes or those resulting from sociological changes in the demographic structure [Czempas 2010]. In the literature, the risk related to the investment activity of public sector entities is considered as one of the elements of specific risk [van Greuning, Brajovic-Bratanovic 2003]. Very often the impact of this risk is analyzed taking into account the risk of financial liquidity, interest rate or foreign exchange risk [Filipiak 2011, 2016; Bock, Trück 2011; Kamiński 2012; Kata 2015; Ali 2015].

The above presented approaches do not cover all the groups of risk that can be found in the literature, but they are designed to order the existing risks spatially and directionally which facilitates their recognition, categorization and the analysis of their incidence. Moreover, it should be noted that their border lines are blurred and the very nature of risk is volatile. All this means that the same risk factor may bring varying consequences. This lack of clear differences among the risk factors makes their categorization difficult. Therefore a given phenomenon is identified and then we search for interrelations among its contributory factors. Next, the power of interactions of factors and of their influence on the phenomenon. This means that risk can be triggered by many factors of diverse impact that are often difficult to select and estimate.

\section{Data and research approach}

\subsection{Data and methods}

Because risk is present in both the process of investment decision-making and during the investment project implementation, it has been assumed that its reflection is the level of failure in meeting the budget objectives in voivodships (Poland's largest

\footnotetext{
${ }^{5}$ See: [Filipiak 2011; Rechul 2015].

${ }^{6}$ The approach to risk measurement in public sector entities is represented by: [Lam 2003; Filipiak 2011, 2016; Kamiński 2012; Kata 2015].
} 
administrative units) which in Poland correspond to regions that are specified by the European Union as NUTS 2 [Czempas 2010, 2013].7 The author has posed the following research questions:

1. How great were the disparities between planned and actually incurred investment costs in Polish regions in 2011-2015?

2. Did systematic changes in the level of inconsistency between the planned and actually incurred costs take place in the observed period?

3. Was the rate of failure to meet investment plans correlated with the rate of failure to meet operational financial plans?

The above questions are expected to corroborate the thesis that the risk accompanying the regional management processes finds its reflection in the level of failures to meet those budget objectives that refer to investment costs. With a view to confirm the adopted thesis and taking into consideration the fundamental changes in Polish law regulating the way how expenditure is positioned in the budgets of public entities (including regions), as well as in order to ensure comparability in time, the author bases her analysis on source data from 2011-2015. The source data on the volume of budgeted expenditure come from budgetary resolutions from all the Polish regions, thus covering $100 \%$ of the Polish population. The source data concerning actual expenditure come from the reports on budget implementation in voivodships and from the databases of the Regional Audit Boards.

In order to identify the unrealised budget expenditure, the author will use a comparative analysis between the budget adopted for a given year (without further amendments) and the actually executed budget. ${ }^{8}$ The analysis covers the total expenditure, the volume of current expenditure (illustrating the implementation of current tasks) and the volume of financial expenditure (illustrating the investment activity). It has been assumed that the level of failure to execute the budget objectives is measured with the deviation between the planned and actually incurred costs and that it is expressed as a percentage. Using the Czempas [2010, 2013] approach, the following ranges of deviations have been adopted: very small (0-2\%), small (2-5\%), average (5-10\%), big (10-20\%), very big (20-50\%), extreme (more than 50\%).

The study applies statistical measures of average level and of variation: the mean that allows us to illustrate the average level of execution/failure to execute investment expenditure plans, the area of variation expressed as the difference between the maximum and the minimum value of a given characteristic (total expenditure,

${ }^{7}$ This approach to risk analysis differs from the one by Bock, Trück [2011]. The approach presented in the reference literature refers to the measurement of the effectiveness of individual projects. Czempas' [2010] approach is based on deviations between the planned and actually incurred investment costs. It takes into account specific Polish regulations concerning investments, which is not possible when analysing the effectiveness of realised projects.

${ }^{8}$ Polish law permits changes to the budget during the budgetary year. The changed costs are regarded as planned. For instance, the change introduced on Dec 30 will be a cost planned for a given year, while when the change is introduced on Dec 31 - as an executed budget objective. 
current expenditure, investment expenditure), standard deviation, and coefficient of variability. These measures provide an answer to the question of what percentage of the average level the standard deviation is. This in turn shows how much the examined values deviate from the obtained mean. Standard deviation $(s)$ is: ${ }^{9}$

$$
S=\sqrt{\frac{\sum_{i=1}^{n}\left(x_{i}-\mathrm{x}^{\prime}\right)^{2}}{n}},
$$

where: $x_{i}$ - subsequent values of a given random variable in a sample, $\mathrm{x}^{\prime}-$ the arithmetical mean of the sample, $n$-number of elements in the sample.

The coefficient of variability $\left(V^{10}\right)$ is determined in accordance with the following formula: ${ }^{11}$

$$
V=\frac{s}{\mathrm{x}^{\prime}}
$$

where: $s$ - the standard deviation, $\mathrm{x}^{\prime}$ - the arithmetical mean of the sample.

Then, in order to find out if the unrealised financial expenditure is correlated with the level of failure to meet the planned current expenditure, the Pearson coefficient of correlation is used: ${ }^{12}$

$$
r_{x y}=\frac{\sum_{\mathrm{i}=1}^{\mathrm{n}}\left(x_{i}-x^{\prime}\right)\left(y_{i}-y^{\prime}\right)}{\sqrt{\sum_{\mathrm{i}=1}^{\mathrm{n}}\left(x_{i}-x^{\prime}\right)^{2}} \sqrt{\sum_{\mathrm{i}=1}^{\mathrm{n}}\left(y_{i}-y^{\prime}\right)^{2}}},
$$

where: $x_{i}$ - subsequent observed values of the first examined variable, $\mathrm{x}^{\prime}-$ the arithmetical mean of the first examined variable, $y_{i}-$ subsequent observed values of the second examined variable, $\mathrm{y}^{\prime}$ - the arithmetical mean of the second examined variable, $n$-number of elements in the sample.

\subsection{Discussion of study results}

The analysis of the failure to execute the budget objectives is made in reference to the planned and actually incurred investment costs (Table 1) and in reference to the planned and actually incurred current expenses (Table 2).

\footnotetext{
${ }^{9}$ Formula by Aczel [2006].

${ }^{10}$ It has been assumed that the coefficient takes: $V<0.20$ - poor variability, $0.2 \%<V<0.4-$ average variability, $0.40 \%<V<1$ - large variability, $1<V<0.5$ - very large variability, $V>1 \%$ - extremely large variability.

${ }^{11}$ Formula by Talaga [1998].

${ }^{12}$ Formula by Aczel [2006].
} 
Table 1. The execution of budgeted investment expenditure in Polish regions in 2011-2015

\begin{tabular}{|c|c|c|c|c|c|c|c|c|c|c|}
\hline \multirow{2}{*}{$\begin{array}{l}\text { Item } \\
\text { number }\end{array}$} & \multirow{2}{*}{$\begin{array}{l}\text { Region } \\
\text { voivodship }\end{array}$} & \multicolumn{5}{|c|}{$\begin{array}{l}\text { Level of failure to execute investment plans } \\
\text { by years (\%) }\end{array}$} & \multirow{2}{*}{$\begin{array}{c}\text { Maximum - } \\
\text { minimum }\end{array}$} & \multirow{2}{*}{ Mean } & \multirow{2}{*}{$\begin{array}{l}\text { Variability } \\
\text { coefficient }\end{array}$} & \multirow{2}{*}{$\begin{array}{l}\text { Standard } \\
\text { deviation }\end{array}$} \\
\hline & & 2011 & 2012 & 2013 & 2014 & 2015 & & & & \\
\hline 1 & Dolnośląskie & 27.84 & -4.69 & 26.94 & 11.75 & 20.83 & 32.53 & 16.54 & 0.82 & 13.49 \\
\hline 2 & $\begin{array}{l}\text { Kujawsko- } \\
\text {-Pomorskie }\end{array}$ & 54.97 & 40.41 & 23.45 & 20.45 & -17.95 & 72.92 & 24.27 & 1.13 & 27.39 \\
\hline 3 & Lubelskie & 71.56 & 79.97 & 84.60 & 82.13 & 79.17 & 13.04 & 79.48 & 0.06 & 4.91 \\
\hline 4 & Lubuskie & -43.66 & 0.29 & 18.91 & -32.96 & -22.43 & 62.57 & -15.97 & -1.59 & 25.39 \\
\hline 5 & Łódzkie & 16.20 & 9.57 & 27.29 & 43.07 & 0.68 & 42.38 & 19.36 & 0.85 & 16.43 \\
\hline 6 & Małopolskie & -9.13 & 23.28 & 9.78 & 24.75 & 9.41 & 33.88 & 11.62 & 1.18 & 13.67 \\
\hline 7 & Mazowieckie & 43.30 & 49.52 & 43.16 & 33.36 & -4.99 & 54.52 & 32.87 & 0.67 & 21.94 \\
\hline 8 & Opolskie & 20.13 & 15.82 & 9.33 & -0.001 & 16.68 & 20.132 & 12.39 & 0.64 & 7.95 \\
\hline 9 & Podkarpackie & 34.39 & 48.98 & 38.84 & 20.162 & -6.69 & 55.66 & 27.14 & 0.79 & 21.56 \\
\hline 10 & Podlaskie & 4.51 & 5.19 & 14.26 & 19.778 & -22.36 & 42.14 & 4.28 & 3.79 & 16.20 \\
\hline 11 & Pomorskie & -25.12 & -21.05 & -127.04 & -2.636 & -2.78 & 124.26 & -35.72 & -1.46 & 52.07 \\
\hline 12 & Śląskie & 16.10 & 19.30 & 37.41 & 40.910 & -64.71 & 105.62 & 9.80 & 4.39 & 43.05 \\
\hline 13 & Świętokrzyskie & 54.77 & 29.54 & 16.54 & 16.875 & -2.24 & 57.01 & 23.10 & 0.91 & 21.03 \\
\hline 14 & $\begin{array}{l}\text { Warmińsko- } \\
\text {-Mazurskie }\end{array}$ & 24.86 & 48.13 & 35.45 & -49.411 & 34.42 & 97.539 & 18.69 & 2.08 & 38.96 \\
\hline 15 & Wielkopolskie & 21.07 & 18.16 & 7.45 & 10.821 & -25.12 & 46.19 & 6.47 & 2.86 & 18.49 \\
\hline 16 & \begin{tabular}{|l} 
Zachodnio- \\
pomorskie
\end{tabular} & 23.97 & 10.34 & 6.40 & 4.825 & -3.28 & 27.25 & 8.45 & 1.18 & 9.99 \\
\hline \multicolumn{2}{|c|}{ Minimum } & -25.12 & -21.05 & -127.04 & -32.957 & -64.71 & 13.04 & -35.72 & & \\
\hline \multicolumn{2}{|c|}{ Maximum } & 71.56 & 79.97 & 84.60 & 82.130 & 79.17 & 124.26 & 79.48 & & \\
\hline \multicolumn{2}{|c|}{ Maximum - minimum } & 96.68 & 101.01 & 211.63 & 115.09 & 143.88 & 111.22 & 115.21 & & \\
\hline \multicolumn{2}{|l|}{ Mean } & 20.98 & 23.30 & 17.05 & 15.24 & -0.71 & 55.48 & 15.17 & & \\
\hline \multicolumn{2}{|c|}{ Variability coefficient } & 29.59 & 25.26 & 43.06 & 30.11 & 31.07 & 31.25 & 23.97 & & \\
\hline \multicolumn{2}{|c|}{ Standard deviation } & 1.41 & 1.08 & 2.53 & 1.98 & -43.74 & 0.56 & 1.58 & & \\
\hline
\end{tabular}

Source: own study based on database of the National Board of Regional Audit Boards (2007-2015).

The applied measures and the obtained calculation results referring to the investment expenditure lead to the following detailed conclusions:

- The analysis shows that in the analysed period of time the unrealised budgeted investment expenditure was considerable and that there were large disparities among the regions. In the majority of the Polish regions the deviations of actual investment expenditure from the budgeted one were very large, i.e. exceeding $20 \%$.

- The average level of failure in meeting the budgeted investment expenditure exceeded $15 \%$. The average values in individual years of the period varied. In 
Table 2. The execution of budgeted current expenditure in Polish regions in 2011-2015

\begin{tabular}{|c|c|c|c|c|c|c|c|c|c|c|}
\hline \multirow{2}{*}{$\begin{array}{l}\text { Item } \\
\text { number }\end{array}$} & \multirow{2}{*}{$\begin{array}{c}\text { Region } \\
\text { voivodship }\end{array}$} & \multicolumn{5}{|c|}{$\begin{array}{l}\text { Level of failure to execute investment plans } \\
\text { by years (\%) }\end{array}$} & \multirow{2}{*}{$\begin{array}{c}\text { Maximum - } \\
\text { minimum }\end{array}$} & \multirow{2}{*}{ Mean } & \multirow{2}{*}{$\begin{array}{l}\text { Variability } \\
\text { coefficient }\end{array}$} & \multirow{2}{*}{$\begin{array}{l}\text { Standard } \\
\text { deviation }\end{array}$} \\
\hline & & 2011 & 2012 & 2013 & 2014 & 2015 & & & & \\
\hline 1 & Dolnośląskie & 27.84 & -4.69 & 26.94 & 11.75 & 20.83 & 32.53 & 16.54 & 0.82 & 13.49 \\
\hline 2 & $\begin{array}{l}\text { Kujawsko- } \\
\text {-Pomorskie }\end{array}$ & 54.97 & 40.41 & 23.45 & 20.45 & -17.95 & 72.92 & 24.27 & 1.13 & 27.39 \\
\hline 3 & Lubelskie & 71.56 & 79.97 & 84.60 & 82.13 & 79.17 & 13.04 & 79.48 & 0.06 & 4.91 \\
\hline 4 & Lubuskie & -43.66 & 0.29 & 18.91 & -32.96 & -22.43 & 62.57 & -15.97 & -1.59 & 25.39 \\
\hline 5 & Łódzkie & 16.20 & 9.57 & 27.29 & 43.07 & 0.68 & 42.38 & 19.36 & 0.85 & 16.43 \\
\hline 6 & Małopolskie & -9.13 & 23.28 & 9.78 & 24.75 & 9.41 & 33.88 & 11.62 & 1.18 & 13.67 \\
\hline 7 & Mazowieckie & 43.30 & 49.52 & 43.16 & 33.36 & -4.99 & 54.52 & 32.87 & 0.67 & 21.94 \\
\hline 8 & Opolskie & 20.13 & 15.82 & 9.33 & -0.001 & 16.68 & 20.132 & 12.39 & 0.64 & 7.95 \\
\hline 9 & Podkarpackie & 34.39 & 48.98 & 38.84 & 20.162 & -6.69 & 55.66 & 27.14 & 0.79 & 21.56 \\
\hline 10 & Podlaskie & 4.51 & 5.19 & 14.26 & 19.778 & -22.36 & 42.14 & 4.28 & 3.79 & 16.20 \\
\hline 11 & Pomorskie & -25.12 & -21.05 & -127.04 & -2.636 & -2.78 & 124.26 & -35.72 & -1.46 & 52.07 \\
\hline 12 & Śląskie & 16.10 & 19.30 & 37.41 & 40.910 & -64.71 & 105.62 & 9.80 & 4.39 & 43.05 \\
\hline 13 & Świętokrzyskie & 54.77 & 29.54 & 16.54 & 16.875 & -2.24 & 57.01 & 23.10 & 0.91 & 21.03 \\
\hline 14 & $\begin{array}{l}\text { Warmińsko- } \\
\text {-Mazurskie }\end{array}$ & 24.86 & 48.13 & 35.45 & -49.411 & 34.42 & 97.539 & 18.69 & 2.08 & 38.96 \\
\hline 15 & Wielkopolskie & 21.07 & 18.16 & 7.45 & 10.821 & -25.12 & 46.19 & 6.47 & 2.86 & 18.49 \\
\hline 16 & $\begin{array}{l}\text { Zachodnio- } \\
\text { pomorskie }\end{array}$ & 23.97 & 10.34 & 6.40 & 4.825 & -3.28 & 27.25 & 8.45 & 1.18 & 9.99 \\
\hline \multicolumn{2}{|c|}{ Minimum } & -25.12 & -21.05 & -127.04 & -32.957 & -64.71 & 13.04 & -35.72 & & \\
\hline \multicolumn{2}{|c|}{ Maximum } & 71.56 & 79.97 & 84.60 & 82.130 & 79.17 & 124.26 & 79.48 & & \\
\hline \multicolumn{2}{|c|}{ Maximum - minimum } & 96.68 & 101.01 & 211.63 & 115.09 & 143.88 & 111.22 & 115.21 & & \\
\hline \multicolumn{2}{|l|}{ Mean } & 20.98 & 23.30 & 17.05 & 15.24 & -0.71 & 55.48 & 15.17 & & \\
\hline \multicolumn{2}{|c|}{ Variability coefficient } & 29.59 & 25.26 & 43.06 & 30.11 & 31.07 & 31.25 & 23.97 & & \\
\hline \multicolumn{2}{|c|}{ Standard deviation } & 1.41 & 1.08 & 2.53 & 1.98 & -43.74 & 0.56 & 1.58 & & \\
\hline
\end{tabular}

Source: own study based on the database of the National Board of Regional Audit Boards (2007-2015).

2011 and 2012 they were higher than the average in the total period of observation, in 2013 and 2014 they fluctuated around that average, while in 2015 the average level of unrealised investment plans was negative.

- Negative deviations of investment expenditure from the budgeted objectives meant that the incurred investment expenditure was higher than planned. It is worth noting that in the Pomorskie voivodship the value of the deviation was negative throughout the whole period of observation.

- In 2015 ten out of the fifteen regions saw a negative deviation of incurred investment costs from the planned expenditure. It was the only year when such a large number of voivodships spent more on investments that had been planned in their annual budgets. 
- In the years of 2012, 2014 and 2015, in the vast majority of regions the disparity between the budgeted and actually incurred investment expenditure was lower than the annual average, in contrast to 2011 and 2013 when the trend was opposite.

- The smallest deviations from the planned investment expenditure were seen in the West Pomeranian (at the average and high level) and in Małopolskie (high and very high level) voivodships.

- The highest values, denoting very big and extreme discepancies between the planned and incurred investment expenditure, were recorded in the Lubelskie, Mazowieckie, Podkarpackie, Pomorskie, Świętokrzyskie and Kujawsko-Pomorskie voivodships.

- The greatest variability range of the deviation of the funds actually spent on investments from the budget objectives was recorded in the Lubuskie, Mazowieckie, Warmińsko-Mazurskie and Opolskie voivodships, while the narrowest - in the Wielkopolskie, Podkarpackie, Śląskie, Świętokrzyskie and Małopolskie.

The general conclusion drawn from the study into the deviations of the actually incurred investment costs from the investment expenditure planned in the regional annual budgets in Poland confirms significant disparities between those two values. The study found as well that in the period of observation, systematic changes took place in the level of inconsistency between the budgeted and executed investment project costs. The research confirmed the assumption that the risk occurs in the level of voivodship investment activity undertaken by local self-government units. The discrepancies found between the planned expenditures and those implemented in the voivodship budgets in the part of investment expenditures point to this risk (risk of operational nature). The indicated risk leads to a limitation of the current tasks being performed, which leads to a limitation of the quality or the quality and quantity of goods and services provided by the voivodships in a given period (the current activity of LGUs). Both the average ranges of these disparities by regions and in individual years and the variability measures corroborate the above conclusion.

In order to answer the question if the level of unrealised financial expenditure was correlated with the level of unrealised current expenses, it seems essential to start with an analysis of the deviations of the incurred current expenses from the planned ones and then to determine the Pearson coefficients of correlation between investment and current expenses in the subsequent years (Table 3). The analysis of data concerning current expenses from Table 2 leads to the following conclusions:

- The level of failure to meet budgeted current expenses in the period of observation is average and high. In the majority of Polish regions the deviations of actually incurred current costs from the budget objectives do not exceed $20 \%$.

- The greatest area of deviation variability in terms of realised and unrealised current expenses was seen in the Lubuskie, Lubelskie, Mazowieckie, Opolskie, Warmińsko-Mazurskie voivodships. 
- In 2012, 2014 and 2015 there was a clear predominance of the regions where the discrepancies between the budgeted and realised current expenditure were lower than the average in a given year. In 2011 and 2013 the tendency was reversed.

- The greatest variability range of the deviation of the funds actually spent from the budgeted current expenditure was seen in the Podkarpackie, Łódzkie, Kujawsko-Pomorskie, Mazowieckie, Podkarpackie, Warmińsko-Mazurskie, Wielkopolskie and Zachodniopomorskie voivodships.

Table 3. Coefficient of correlation between the level of failure to realise investment expenditure and current expenditure as well as the measures

\begin{tabular}{|c|c|c|c|c|c|c|c|c|}
\hline & \multicolumn{5}{|c|}{ Years } & \multirow{2}{*}{ Mean } & $\begin{array}{c}\text { Variability } \\
\text { coefficient }\end{array}$ & $\begin{array}{c}\text { Standard } \\
\text { deviation }\end{array}$ \\
\cline { 2 - 9 } Regions & 2011 & 2012 & 2013 & 2014 & 2015 & & 0.37 & 0.21 \\
\cline { 2 - 8 } & 0.69 & 0.76 & 0.24 & 0.70 & 0.50 & 0.58 & 0.37 \\
\hline
\end{tabular}

Source: own study.

The analysis of the Pearson coefficient of correlation between the level of failure to meet budget objectives concerning investment and current expenditure in subsequent years (Table 3) reveals that in 2011, 2012 and 2014 the values oscillated around 0.7 , while in 2015 the coefficient values were lower, at 0.5 . The results show that there was a statistical relation between the level of unrealised investment expenditure and current expenditure in subsequent years, which means that in those years similar factors determined the success or failure to meet the budget objectives in terms of investment and current expenditure. There was a relatively strong correlation between the level of unrealised investment expenses and current expenses. In 2013 there was no statistical relation between the level of failure to realise budgeted investment and current expenses in subsequent years, which allows for the conclusion that between those levels there were no relevant statistical relations. The results show that very different factors determine the success or failure to meet budget objectives concerning current expenses and investment expenses. Therefore different categories of risk to which regional budgets are exposed to should be identified for these two types of expenditure.

\section{Conclusion}

There is a significant risk associated with the investment projects implemented by Polish regions. The occurrence of this risk has been confirmed in research conducted by Czempas [2010] in counties (Polish 'powiat'). The study extends research into the occurrence of risk in the investment activities of regions and confirms the assumptions made earlier in large territorial units [Czempas 2010, 2013]. Therefore the thesis has been confirmed that the risk affecting the voivodship management processes finds its reflection in the levels of failure to meet the budget objectives in 
terms of investment expenditure. In 2011 and 2013, as well as in 2014 and 2015, there was a strong correlation between the level of failure to meet budgeted investment objectives and current expenses.

Despite the confirmation of the thesis and verification of the research questions, it is worth noting that the risk of failure to realise budgeted investment objectives in the regions is strongly conditioned by external, or independent, factors. It seems necessary to search for the risk factors that are responsible for significant deviations of the actually incurred investment costs from the planned ones. Although the reference literature points to some typical risk factors (such as difficulty in expenditure planning, competence of the managerial staff or political decisions), from the point of view of regional management it is worthwhile to discover the specific risk factors. This research task is perceived by the authors as necessary to be carried out in the future.

A factor which is common for all the regions, independent and classifiable as a systematic risk, is access to European Union funds to co-finance investment programmes. It is in particular the terms, procedures and times of the funds acquisition that trigger this risk factor. The Polish law requires to include in the budgets the volume of investment funds to be acquired from the EU, even though the project has not been evaluated and the EU funds have not been allocated yet. This particular risk factor is of great relevance and should be analysed in detail in the Polish regions. This research task is perceived by the authors as necessary to be carried out in the future, especially that research on this issue using the Delphi method has already been started [Bock, Trück 2011], and the method used has not been verified in Polish JSTs.

Another problematic issue is the procedural risk belonging to the group of systematic risks. A considerable reason for inaccurately planned budgets is the complexity of procedures before and during the investment project implementation, mainly the tendering procedures specified in the Public Procurement Act that imposes multiple budget corrections, thus leading to delays in the implementation of many investment projects, especially in their preparatory phase. The indicated factors are very difficult to disclose. It is known that they occur, but only when LGUs implementing investment tasks in the public-private partnership (PPP) procedure, they are disclosed. In accordance with the applicable law, transactions are not included in the budget unless there is a risk factor affecting the LGU budget.

Not insignificant for the observed deviations of actually incurred investment expenditure from the budget objectives is the specific risk associated with the human factor, i.e. with the quality of qualifications of regional budget planners or investment decision-makers. The risk factors include: the lack of professional expertise in finance and accounting, the application of the historical method of investment planning, and the lack of forecasting skills. This particular risk is also connected with the systematic risk of frequent changes in legal regulations due to political pressure.

It remains also open to consideration the issue related to extending the conducted research with factors such as: financial liquidity, interest rate or foreign exchange 
risk. In Poland, such a study has not been carried out. However, the research was carried out in relation to individual factors [Filipiak 2011, 2016; Kamiński 2012; Kata 2015]. Conducting such a study would give wider possibilities of inference, just like in Bock and Trück [2012] or Ali [2015].

Each region should be aware of the existing risks, and see the specific risk factors that may affect the investment projects' successful implementation. The complexity of investment projects makes it necessary to consider all the risks associated with their implementation. They are the factors that can have a considerable impact on the disparities between the incurred and planned investment expenditure.

\section{Bibliography}

Aczel A.D., 2006, Statystyka w zarządzaniu, Wydawnictwo Naukowe PWN, Warszawa.

Ali G., 2015, Factors affecting public investment in manufacturing sector of Pakistan, European Journal of Economic Studies, vol. 13, Iss. 3, pp. 122-130.

Bock K., Trück S., 2011, Assessing uncertainty and risk in public sector investment projects, Technology and Investment, no. 2 pp. 105-123.

Czempas J., 2010, Ryzyko w działalności inwestycyjnej gmin. Niezgodność planów z wykonaniem inwestycji w gminach i powiatach województwa śląskiego (2004-2009), Finanse Komunalne, no. 9 pp. 18-35.

Czempas J., 2013, Skłonność jednostek samorządu terytorialnego do inwestowania. Ujęcie ilościowe na przykładzie miast na prawach powiatu województwa śląskiego, Wydawnictwo Uniwersytetu Ekonomicznego w Katowicach, Katowice.

Filipiak B.Z., 2010, Ryzyko decyzji finansowych podejmowanych przez organy samorzadowe w świetle ustawy o finansach publicznych, Zeszyty Naukowe WSB w Poznaniu, no. 26, pp. 115-124.

Filipiak B.Z., 2011, Finanse samorządowe. Nowe wyzwania bieżace i perspektywiczne, Difin, Warszawa.

Filipiak B.Z., 2016, Instrumenty i narzędzia zarządzania dtugiem-ocena spójności z wieloletnia prognoza finansowa, Finanse Komunalne, no. 11 pp. 29-40.

Graczyk A., 2008, Zarządzanie inwestycjami komunalnymi. Dobra praktyka w pozyskiwaniu funduszy europejskich, Branta, Bydgoszcz-Zielona Góra.

Grzybowski W., 1984, Ryzyka, innowacje i decyzje gospodarcze, Wydawnictwo UMCS, Lublin.

Jaafari A., 2001, Management of risks, uncertainties and opportunities on projects: Time for a fundamental shift, International Journal of Project Management, vol. 19, no. 2 pp. 89-101.

Jajuga K., Jajuga T., 1996, Inwestycje, PWN, Warszawa.

Kamiński A., 2012, Finansowanie dtużne w jednostkach samorządu terytorialnego, Lex a Wolters Kluwer business, Warszawa.

Kata R., 2015, Ryzyko finansowe w kontekście zadtużenia jednostek samorzadu terytorialnego $w$ Polsce, Optimum. Studia Ekonomiczne, no. 4 (76) pp. 54-71.

Knight F.H., 2005, Risk. Uncertainty and Profit, Cosimo Inc., New York.

Komunikat Nr 6 Ministra Finansów z dnia 6 grudnia 2012 r. w sprawie szczegółowych wytycznych dla sektora finansów publicznych w zakresie planowania i zarządzania ryzykiem (Dz. Urz. Min. Fin. poz. 56).

Krajowa Rada Regionalnych Izb Obrachunkowych (2007-2015), Sprawozdania z działalności regionalnych izb rachunkowych i wykonania budżetu przez JST za lata 2006-2014, https:/www.rio.gov.pl/ modules.php?op=modload\&name=HTML\&file=index\&page=publ_sprawozdania (7.12.2016).

Kulp C.A., 1928, Casualty Insurance, Ronda Press, New York. 
Lam J., 2003, Risk Management from Incentives to Control, Wiley, New York.

Nahotko S., 2001, Ryzyko ekonomiczne w działalności gospodarczej, Wydawnictwo OPO, Bydgoszcz.

Pera J., 2012, Niepewność a problem mitygacji ryzyka w przedsiębiorstwie, Zarządzanie i Finanse, R.10, no. 1, 1 pp. 91-101.

Pfeffer J., 1956, Insurance and Economic Theory, Irving Inc. Homewood, Illinois.

Piyatrapoomi N., Kumar A., Setunge S., 2004, Framework for Investment Decision-Making under Risk and Uncertainty for Infrastructure Asset Management, Research in Transportation Economics, vol. 8, no. 1, pp. 199-214.

Poniatowicz M., 2014, Wplyw kryzysu gospodarczego na systemy finansowe jednostek samorzadu terytorialnego na przykładzie największych miast $w$ Polsce, CeDeWu, Warszawa.

Poniatowicz, M., Salachna, J.M, Perło, D., 2010, Efektywne zarządzanie dtugiem w jednostce samorzadu terytorialnego, Oficyna a Wolters Kluwer business, Warszawa.

Rechul H., 2015, Cele i zarzadzanie ryzykiem jako elementy kontroli zarzadczej w jednostkach sektora finansów publicznych, Prace Naukowe Uniwersytetu Ekonomicznego we Wrocławiu, nr 403, pp. 238-247.

Rowe D.W., 1997, An Anatomy of Risk, R.E. Krieger Publishing Company, New York.

Roy S.F., Singell D., 1987, Knight on Risk and Uncertainty, The Journal of Political Economy, vol. 95, no. 2 pp. 394-406.

Sadowy M., 2006, Zarzadzanie funkcjonowaniem i rozwojem infrastruktury komunalnej, [w:] Sochacka-Krysiak H. (red.), Zarzadzanie gospodarka i finansami gminy, SGH, Warszawa.

Stiglitz J., 2004, Ekonomia sektora publicznego, Wydawnictwo Naukowe PWN, Warszawa.

Talaga L., 1998, Metody analizy struktury, [in:] Hozer J. (ed.), Statystyka. Opis statystyczny, Stowarzyszenie Pomoc i Rozwój, Szczecin.

Tarczyński W., Mojsiewicz M., 2001, Zarządzanie ryzykiem, PWE, Warszawa.

van Greuning H., Brajovic-Bratanovic S., 2003, Banking Risk Analysis and Management, Irecson Publishing House, Bucharest.

Vose D., 2000, Risk Analysis - A Quantitative Guide, 2nd Edition, John Wiley \& Sons Ltd., Chichester.

\section{RYZYKO W DZIAŁALNOŚCI INWESTYCYJNEJ REGIONÓW W POLSCE}

Streszczenie: Działalność inwestycyjna regionów obarczona jest wysokim ryzykiem. Ryzyko to wynika z samej istoty realizacji przedsięwzięć inwestycyjnych, które prowadzą regiony w Polsce, ale jest również związane z niezrealizowaniem budżetu. Celem badania jest ocena rozmiarów występujących rozbieżności między wydatkami inwestycyjnymi zaplanowanymi a wykonanymi oraz ustalenie, czy w kolejnych latach zachodzą systematyczne zmiany poziomu niezgodności wielkości planowanych i zrealizowanych. Cel ten został osiągnięty poprzez przedstawienie specyfiki podejścia do pomiaru ryzyka występującego w działalności inwestycyjnej jednostek samorządu terytorialnego. Do badań przyjęto jednostki samorządu wojewódzkiego. Badania empiryczne pozwoliły odpowiedzieć na trzy pytania badawcze: Jak duże były w latach 2011-2015 rozbieżności między zrealizowanymi i zaplanowanymi wydatkami inwestycyjnymi w regionach w Polsce? Czy w analizowanych latach zachodzą systematyczne zmiany poziomu niezgodności wielkości planowanych i zrealizowanych? Czy stopień niezrealizowania wydatków majątkowych jest skorelowany ze stopniem niezrealizowania wydatków bieżących?

Słowa kluczowe: jednostki samorządu terytorialnego, wydatki inwestycyjne, infrastruktura, ryzyko finansowe. 